\title{
UJI EFEKTIFITAS INSEKTISIDA NABATI (EKSTRAK DAUN PEPAYA) DAN INSEKTISIDA KIMIA (ALIKA) DALAM PENGENDALIAN HAMA PENGGEREK POLONG (Etiella zinkenella) PADA TANAMAN KACANG KEDELAI
}

(Glycine max Merril.)

\author{
Samsinar Harahap ${ }^{\left.1^{*}\right)}$, Muhammad Agung Permadi ${ }^{2 *}$ \\ Email: samsinar@um-tapsel.ac.id \\ ${ }^{1,2 *}$ Fakultas Pertanian Universitas Muhammadiyah Tapanuli Selatan, Sumatera Utara
}

\begin{abstract}
ABSTRAK
Tujuan penelitian ini adalah untuk mengetahui Uji Efektifitas Insektisida Nabati (Ekstrak Daun Pepaya) Dan Insektisida Kimia (Alika) Dalam Pengendalian Hama Penggerek Polong (Etiella zinkenella) Pada Tanaman Kacang Kedelai (Glycine max Merril.). Penelitian ini dilaksanakan di Desa Tolang Julu, Kecamatan Sayur Matinggi, Kabupaten Tapanuli Selatan, dengan ketinggian tempat kurang lebih 250 meter di atas permukaan laut. Penelitian ini dilakukan dengan menggunakan metode rancangan acak kelompok non faktorial dengan 9 perlakuan. Berdasarkan hasil analisis secara statistik pada perlakuan insektisida nabati (ekstrak daun pepaya) dan Insektisida Kimia (Alika) dalam mengendalikan hama penggerek polong pada tanaman kacang kedelai menunjukkan pengaruh yang nyata terhadap parameter persentase serangan hama penggerek polong per plot pada umur pengamatan 5 mst dan 6 mst, parameter tingkat kerusakan yang ditimbulkan oleh serangan hama penggerek polong per sampel pada umur pengamatan 5 mst dan 6 mst, parameter produksi biji basah dan biji kering per plot dan pada parameter produksi biji basah dan biji kering per hektar. Berdasarkan hasil analisis secara statistik pada perlakuan insektisida nabati (ekstrak daun pepaya) dan Insektisida Kimia (Alika) dalam mengendalikan hama penggerek polong pada tanaman kacang kedelai menunjukkan pengaruh tidak nyata terhadap pada parameter produksi biji basah dan biji kering per sampel. Perlakuan Insektisida nabati (Ekstrak daun pepaya) yang terbaik yaitu $\mathrm{I}^{3}$ dengan dosis $1,5 \mathrm{~kg} / 10$ liter air. Perlakuan Insektisida kimia (Alika) yang terbaik yaitu $\mathrm{I}^{8}$ dengan dosis $0,5 \mathrm{ml} /$ liter air.
\end{abstract}

Kata Kunci : Insektisida nabati (Ekstrak daun pepaya), kacang kedelai, Insektisida kimia (Alika) 


\section{PENDAHULUAN}

Kedelai merupakan salah satu tanaman pangan penting bagi penduduk Indonesia sebagai sumber protein nabati, bahan baku industri pakan ternak, dan bahan baku industri pangan. Kandungan proteinnya lebIh tinggi dibanding dengan tanaman pangan lainnya, yaitu berkisar antara 35-40\% (Suprapto, 2008).

Sebagai sumber utama protein nabati dan minyak biji yang dapat dimakan kedelai tidak diragukan lagi merupakan legum pangan terpenting didunia. Walaupun terutama ditanam untuk menghasilkan biji kering, penggunaan biji muda secara luas, khususnya di Asia timur, menyebabkan kedelai merupakan salah satu sayuran yang penting (Akmal, 2009).

Salah satu kendala dalam peningkatandan stabilisasi produksi kedelai diIndonesia adalah serangan hama (Tengkano, 2007). Penggerekpolong (Etiella zinckenella Treitschke)merupakan salah satu hama utama padapertanaman kedelai di Indonesia, terutamapada sentra-sentra produksi (Tengkano2007). Selain Etiella zinckenella, spesiespenggerek polong lainnya di Indonesiaadalah Etiella hobsoni Butler,spesies yangdominan dan memiliki daerah penyebaranyang luas. Informasimengenai bioekologi dan daerah penyebaranempat spesies penggerek polonglainnya masih terbatas (Dirjen Tanaman Pangan, 2000).

Kehilangan hasil akibat seranganpenggerek polong mencapai 80\%, bahkanpuso apabila tidak ada tindakan pengendalian(Djuwarso et al. 1990). Hingga kini,upaya pengendalian masih mengandalkaninsektisida kimia, namun kehilangan hasilakibat serangan penggerek polong masihbelum teratasi. Untuk meningkatkanefisiensi dan efektivitas pengendalian,telah dilakukan pengkajian bioekologisebagai dasar dalam penyusunan strategipengendalian penggerek polong secaraterpadu (Komisi Pestisida Departemen Pertanian RI, 2000).

Penggunaan pestisida kimia dilingkungan pertanian menjadi masalah yang sangat dilematis. Disatu pihak dengan menggunakan pestisida kimia kehilangan hasil yang diakibatkan organisme pengganggu tanaman (OPT) dapat ditekan, tetapi dilain pihak dapat menimbulkan 
dampak negatif terhadap tanaman dan lingkungan. Alternatif pengendalian hama penyakit yang mudah, praktis, dan relatif aman untuk lingkungan adalah pertisida nabati (Kardiman, A. 2009).

Salah satu pestisida nabati yang dapat digunakan adalah ekstrak daun pepaya. Daun pepaya mengandung bahan aktif "Papain”, sehingga efektif untuk mengendalikan ulat dan hama penghisap. Estrak daun pepaya dapat digunakan psebagai pestisida alami setelah dicampurkan dengan minyak tanah dan detergen. Pestisida alami dari ekstrak daun pepaya memiliki beberapa manfaat, antara lain: dapat digunakan untuk mencegah hama seperti aphid, rayap, hama kecil, dan ulat bulu serta berbagai jenis serangga. (Suharmadji, D., 2001). Salah satu insektisida kimia yang dapat digunakan untuk memberastas hama penggerek polong adalah insektisida dengan nama dagang Alika. Insektisida Alika merupakan insektisida racun kontak dan lamung, berbentuk pekatan yang larut dalam air, berwarna putih kecoklat-coklatan berdaya kerja luas, untuk mengendalikan hama kutu-kutu dan ulat-ulat (Anonymus, 2010).

\section{BAHAN DAN METODE}

Penelitian ini dilaksanakan di Desa Tolang Julu, Kecamatan Sayur Matinggi, Kabupaten Tapanuli Selatan. Penelitian dimulai pada bulan Februari 2018 sampai dengan bulan Juli 2018.

\section{METODE PENELITIAN}

Metode yang digunakan dalam penelitian ini yaitu metode Rancangan Acak Kelompok (RAK) dalam bentuk non factorial dengan 9 perlakuan :

$\mathrm{I}_{0}=$ Kontrol.

$\mathrm{I}_{1}=$ Penggunaan Insektisida Alami (Ekstrak Daun Pepaya dengan bahan 0,5 kg/10 liter air).

$\mathrm{I}_{2}=$ Penggunaan Insektisida Alami (Ekstrak Daun Pepaya dengan bahan 10 kg/10 liter air).).

$\mathrm{I}_{3}=$ Penggunaan Insektisida Alami (Ekstrak Daun Pepaya dengan bahan 1,5 kg/10 liter air).

$\mathrm{I}_{4}=$ Penggunaan Insektisida Kimia (Alika 0,1 ml/l air).

$\mathrm{I}_{5}=$ Penggunaan Insektisida Kimia (Alika 0,2 ml/l air). 
$\mathrm{I}_{6}=$ Penggunaan Insektisida Kimia (Alika 0,3 ml/1 air).

$\mathrm{I}_{7}=$ Penggunaan Insektisida Kimia (Alika 0,4 ml/l air).

$\mathrm{I}_{8}=$ Penggunaan Insektisida Kimia (Alika 0,5 ml/l air).

$$
\begin{aligned}
(\mathrm{t}-1)(\mathrm{r}-1) & \geq 15 \\
(9-1)(\mathrm{r}-1) & \geq 15 \\
\mathrm{r}-1 \geq 15 / 8 & \\
\mathrm{r} \quad & \geq 1,88+1 \\
\mathrm{r} \quad & \geq 2,88 \rightarrow \mathrm{r}=3
\end{aligned}
$$

masing-masing perlakuan tersebut diatas dan diulang (n) sebanyak 3 kali.

Model linear penelitian ini adalah :

$\boldsymbol{Y} \ddot{j} \boldsymbol{j}=\boldsymbol{\mu}+\propto \boldsymbol{i}+\boldsymbol{\beta} \boldsymbol{j}+\boldsymbol{\varepsilon i j}$

$\boldsymbol{Y} \boldsymbol{i} \boldsymbol{j}$ = Hasil pengamatan/respon pada blok ke - i dan perlakuan ke - j

$\boldsymbol{\mu}=$ Nilai tengah rata-rata umum

$\boldsymbol{\beta} \boldsymbol{j}=$ Efek perlakuan pada taraf ke-j

$\propto \boldsymbol{i}=$ Efek blok pada taraf ke-i

$\boldsymbol{\varepsilon} \boldsymbol{i j}$ = Efek galat pada blok ke-i dan perlakuan ke-j

\section{PELAKSANAAN PENELITIAN}

\section{Persiapan Areal}

Areal pertanam di bersihkan dari gulma selanjutnya tanah dicangul, dihaluskan dan diratakan. Kemudian dibuat plot dengan ukuran 120 x 120 m sebanyak 27 plot dengan jarak antar plot $30 \mathrm{~cm}$ dan jarak antar blok $50 \mathrm{~cm}$.

\section{Pemeliharaan}

Pempukan dilakukan bersamaan dengan waktu tanam. Pupuk yang diberikan dengan sistem larikan diantara barisan tanaman. Jenis pupuk yang diberikan adalah Urea $100 \mathrm{~kg} / \mathrm{Ha}, \mathrm{SP}_{36}$ 200gr/Ha, dan KCl 150 Kg/Ha. Setelah dikonversikan/plot menjadi Urea 30 gr/plot, SP ${ }_{36} 60$ gr/plot, dan KCl 45 gr/plot. Penyiraman dilakukan dua kali sehari apabila hujan tidak turun.Penyiangan gulma dilakukan dengan menggunakan cangkul dan garu pada saat yang 
diperlukan.Insektisida diaplikasikan ketanaman sebanyak 4 kali dengan interval 7 hari sekali pada 51, 58, 65 dan 72 hari setelah tanam. Penyemprotan dilakulan dengan menggunakan handsprayer dengan dosis sesuai dengan perlakuan.

\section{Variabel Pengamatan}

Persentase serangan hama penggerek polong perplot (\%), tingkat kerusakan yang ditimbulkan oleh serangan hamapenggerek polong per sampel (\%),produksibiji basah dan biji kering persampel (gr), produksibiji basah dan biji kering per plot (kg), produksi per hektar (ton).

\section{HASIL}

Berdasarkan hasil analisis statistik terhadap variabel pengamatan Persentase serangan hama penggerek polong perplot (\%), tingkat kerusakan yang ditimbulkan oleh serangan hamapenggerek polong per sampel (\%),produksibiji basah dan biji kering persampel (gr), produksibiji basah dan biji kering per plot (kg), produksi per hektar (ton)dapat dilihat pada Tabel

Tabel1 : Persentase Serangan Hama Penggerek Polong Per Plot (\%)

\begin{tabular}{|c|c|c|}
\hline \multirow{2}{*}{ Perlakuan } & \multicolumn{2}{|c|}{$\begin{array}{c}\text { Hasil Uji DMRT Persentase Serangan Hama } \\
\text { Penggerek Polong Per Plot (\%) }\end{array}$} \\
\cline { 2 - 3 } & $5 \mathrm{mst}$ & $6 \mathrm{mst}$ \\
\hline $\mathrm{I}_{0}$ & $0,22 \mathrm{~g}$ & $0,22 \mathrm{f}$ \\
\hline $\mathrm{I}_{1}$ & $0,19 \mathrm{ef}$ & $0,19 \mathrm{e}$ \\
\hline $\mathrm{I}_{2}$ & $0,15 \mathrm{ab}$ & $0,15 \mathrm{ab}$ \\
\hline $\mathrm{I}_{3}$ & $0,13 \mathrm{a}$ & $0,13 \mathrm{a}$ \\
\hline $\mathrm{I}_{4}$ & $0,20 \mathrm{fg}$ & $0,18 \mathrm{~cd}$ \\
\hline $\mathrm{I}_{5}$ & $0,17 \mathrm{~cd}$ & $0,16 \mathrm{bc}$ \\
\hline $\mathrm{I}_{6}$ & $0,14 \mathrm{ab}$ & $0,15 \mathrm{ab}$ \\
\hline $\mathrm{I}_{7}$ & $0,14 \mathrm{ab}$ & $0,14 \mathrm{ab}$ \\
\hline $\mathrm{I}_{8}$ & $0,12 \mathrm{a}$ & $0,13 \mathrm{a}$ \\
\hline
\end{tabular}

Tabel 2 : Tingkat Kerusakan Yang Ditimbulkan OlehSerangan Hama Penggerek Polong Per Sampel (\%)

\begin{tabular}{|c|c|c|}
\hline \multirow{2}{*}{ Perlakuan } & $\begin{array}{c}\text { Tingkat Kerusakan Yang Ditimbulkan Oleh Serangan } \\
\text { Hama Penggerek Polong Per Sampel (\%) }\end{array}$ \\
\cline { 2 - 3 } & $5 \mathrm{mst}$ & $6 \mathrm{mst}$ \\
\hline $\mathrm{I}_{0}$ & $13,88 \mathrm{gh}$ & $17,55 \mathrm{gh}$ \\
\hline $\mathrm{I}_{1}$ & $11,21 \mathrm{fg}$ & $15,92 \mathrm{ef}$ \\
\hline $\mathrm{I}_{2}$ & $7,38 \mathrm{~cd}$ & $14,65 \mathrm{de}$ \\
\hline $\mathrm{I}_{3}$ & $5,80 \mathrm{ab}$ & $10,45 \mathrm{bc}$ \\
\hline
\end{tabular}




\begin{tabular}{|c|c|c|}
\hline $\mathrm{I}_{4}$ & $12,51 \mathrm{hi}$ & $17,26 \mathrm{fg}$ \\
\hline $\mathrm{I}_{5}$ & $10,96 \mathrm{ef}$ & $13,02 \mathrm{~d}$ \\
\hline $\mathrm{I}_{6}$ & $9,92 \mathrm{de}$ & $10,73 \mathrm{bc}$ \\
\hline $\mathrm{I}_{7}$ & $7,36 \mathrm{ab}$ & $8,96 \mathrm{ab}$ \\
\hline $\mathrm{I}_{8}$ & $5,12 \mathrm{a}$ & $7,51 \mathrm{a}$ \\
\hline
\end{tabular}

Tabel 3 : Rataan Produksi Biji Basah Dan Biji Kering Per Sampel(gr)

\begin{tabular}{|c|c|c|}
\hline Perlakuan & $\begin{array}{c}\text { Produksi Biji Basah Per } \\
\text { Sampel (gr) }\end{array}$ & $\begin{array}{c}\text { Produksi Biji KeringPer } \\
\text { Sampel (gr) }\end{array}$ \\
\hline $\mathrm{I}_{0}$ & 189,50 & 139,42 \\
\hline $\mathrm{I}_{1}$ & 190,50 & 141,50 \\
\hline $\mathrm{I}_{2}$ & 191,50 & 141,83 \\
\hline $\mathrm{I}_{3}$ & 192,42 & 144,42 \\
\hline $\mathrm{I}_{4}$ & 189,92 & 141,92 \\
\hline $\mathrm{I}_{5}$ & 190,67 & 142,67 \\
\hline $\mathrm{I}_{6}$ & 192,92 & 141,83 \\
\hline $\mathrm{I}_{7}$ & 192,75 & 144,75 \\
\hline $\mathrm{I}_{8}$ & 195,33 & 145,52 \\
\hline
\end{tabular}

Tabel 4 : Produksi Biji Basah Dan Biji Kering Per Plot (Kg)

\begin{tabular}{|c|c|c|}
\hline Perlakuan & $\begin{array}{c}\text { Hasil Uji DMRTProduksi Biji } \\
\text { Basah Per Plot (Kg) }\end{array}$ & $\begin{array}{c}\text { Hasil Uji DMRTProduksi Biji } \\
\text { KeringPer Plot (Kg) }\end{array}$ \\
\hline $\mathrm{I}_{0}$ & $1,56 \mathrm{a}$ & $1,36 \mathrm{a}$ \\
\hline $\mathrm{I}_{1}$ & $1,61 \mathrm{ab}$ & $1,42 \mathrm{ab}$ \\
\hline $\mathrm{I}_{2}$ & $1,65 \mathrm{~cd}$ & $1,47 \mathrm{~cd}$ \\
\hline $\mathrm{I}_{3}$ & $1,71 \mathrm{ef}$ & $1,53 \mathrm{de}$ \\
\hline $\mathrm{I}_{4}$ & $1,61 \mathrm{ab}$ & $1,42 \mathrm{ab}$ \\
\hline $\mathrm{I}_{5}$ & $1,62 \mathrm{bc}$ & $1,43 \mathrm{ab}$ \\
\hline $\mathrm{I}_{6}$ & $1,68 \mathrm{de}$ & $1,46 \mathrm{bc}$ \\
\hline $\mathrm{I}_{7}$ & $1,73 \mathrm{fg}$ & $1,55 \mathrm{ef}$ \\
\hline $\mathrm{I}_{8}$ & $1,75 \mathrm{gh}$ & $1,60 \mathrm{~g}$ \\
\hline
\end{tabular}

Tabel 5 : Produksi Biji Basah dan Biji Kering Per Hektar (Ton)

\begin{tabular}{|c|c|c|}
\hline Perlakuan & $\begin{array}{c}\text { Produksi Biji Basah } \\
\text { Per Hektar (Ton) }\end{array}$ & $\begin{array}{c}\text { Produksi Biji Kering } \\
\text { Per Hektar (Ton) }\end{array}$ \\
\hline $\mathrm{I}_{0}$ & $0,11 \mathrm{a}$ & $0,10 \mathrm{a}$ \\
\hline $\mathrm{I}_{1}$ & $0,11 \mathrm{ab}$ & $0,10 \mathrm{a}$ \\
\hline $\mathrm{I}_{2}$ & $0,11 \mathrm{ab}$ & $0,10 \mathrm{a}$ \\
\hline $\mathrm{I}_{3}$ & $0,11 \mathrm{bc}$ & $0,10 \mathrm{a}$ \\
\hline $\mathrm{I}_{4}$ & $0,11 \mathrm{bc}$ & $0,10 \mathrm{a}$ \\
\hline $\mathrm{I}_{5}$ & $0,12 \mathrm{~cd}$ & $0,10 \mathrm{a}$ \\
\hline $\mathrm{I}_{6}$ & $0,12 \mathrm{~cd}$ & $0,10 \mathrm{a}$ \\
\hline $\mathrm{I}_{7}$ & $0,12 \mathrm{~cd}$ & $0,10 \mathrm{ab}$ \\
\hline $\mathrm{I}_{8}$ & $0,13 \mathrm{~cd}$ & $0,11 \mathrm{c}$ \\
\hline
\end{tabular}


Berdasarkan Tabel 1, Tabel 2, Tabel 4 dan Tabel 5, diperoleh bahwa perlakuan pemberian Insektisida Nabati dan Insektisida Kimia memberikan pengaruh yang nyata pada pengamatanPersentase serangan hama penggerek polong perplot (\%), tingkat kerusakan yang ditimbulkan oleh serangan hamapenggerek polong per sampel (\%), produksibiji basah dan biji kering per plot (kg), produksi per hektar (ton). Sedangkan pengaruh yang tidak nyata dijumpai pada pengamatan produksi biji basah dan biji kering per sampel (gr).

Pengaruh yang nyata dapat disebabkan karena insektisida nabati dan insektisida kimia yang digunakan sama-sama bermanfaat untuk mengendalikan hama penggerek polong. Insektisida nabati yang digunakan pada penelitian ini adalah ekstrak daun pepaya. Ekstrak daun pepaya merupakan tanaman obat-obatan yang diracik secara alami untuk menekan dan memberantas pertumbuhan hama penggerek polong pada tanaman kedelai memiliki sifat yang tidak meracuni atau membunuh hama penggerek polong secara kontak atau langsung. Sifat alami yang ada pada ekstrak daun papaya yaitu mengandung 35 mg/100 mg. Tocophenol.Daun pepaya muda juga diketahui banyak mengandung zat bernama alkaloid juga enzim papain. Enzim ini identik dengan getah berwarna putih kental. Fungsi dari enzim ini sendiri adalah untuk memecah protein sebab ia bersifat proteolitik. Pada daun pepaya yang sudah tua, senyawa yang dominan justru Fenolik.Menurut Suhartono, bahwa daun pepaya mengandung 3 varian enzim yakni papain sebanyak 10\%, Khimoprotein sebanyak 45\% dan juga Lisozim sebanyak 20\% per 100\%. Enzim khimoprotein sendiri berfungsi sebagai katalisator dalam reaksi hidrolisis antara proteindengan poplipetida. Enzim lisozim berperan sebagai anti-bakteri dan bekerja dengan cara memecah dinding sel pada bakteri. Berbagai taraf dosis yang diberikan ekstrak daun pepaya mampu memberikan pengaruh yang sangat signifikan. Hasil pengamatan secara visual di lapangan pun menunjukkan bahwa ada perubahan dan penurunan persentase serangan hama penggerek polong mulai umur 5 mst dan 6 mst. Sedangkan insektisida kimia yaitu Alika merupakan insektisida yang bekerja secara kontak dan berdaya 
kerja luas yang berbahan aktif lamda sihalotrin 106 g/l. Alika melekat pada permukaan daun dan mengendalikan hama penggerek polong dengan cepat. Alika juga dengan cepat menembus dan menyebar ke seluruh jaringan daun sehingga memberikan perlindungan lebih lama sampai ke tunas-tunas baru (Anonymus,2010).

Pengaruh yang tidak nyata pada pengamatan produksi biji basah dan biji kering per sampel dapat disebabkan oleh dosis dari insektisida yang digunakan masih kurang efektif. Karena semakin tinggi konsentrasi larutan semakin besar pula persentase kematian hama dan diikuti dengan kehilangan hasil yang semakin kecil. Hal ini dapat dilihatpada perlakuan $\mathrm{I}_{0}$ (kontrol) menunjukkan produksi biji basah dan biji kering per sampel yang terendah.Rendahnya produksi biji basah dan biji kering per sampel disebabkan oleh tidak adanya perlakuan yang diaplikasikan baik perlakuan menggunakan insektisida nabati (ekstrak daun pepaya) maupun insektisida kimia (Alika) terhadap tanaman kacang kedelai sehingga populasi hama penggerek polong semakin banyak yang mampu menyebabkan banyaknya polong tanaman kedelai yang terserang (rusak).Hal ini sesuai dengan pendapat Suharto (2007), yang mengatakan bahwa tingginya serangan hama dan penyakit pada suatu tanaman akan menurunkan produksi tanaman tersebut. Dengan diaplikasikannya insektisida alami maupun insektisida kimia dapat menekan serangan hama polong yang terdapat pada pertanaman kedelai sehingga kehilangan produksi dapat ditekan sekecil mungkin.

\section{KESIMPULAN}

Berdasarkan hasil analisis secara statistik pada perlakuan insektisida nabati (ekstrak daun pepaya) dan Insektisida Kimia (Alika)dalam mengendalikan hama penggerek polong pada tanaman kacang kedelai menunjukkan pengaruh yang nyata terhadap parameter persentase serangan hama penggerek polong per plot pada umur pengamatan 5 mst dan 6 mst, parameter tingkat kerusakan yang ditimbulkan oleh serangan hama penggerek polong per sampel pada umur pengamatan 5 mst dan 6 mst, parameter produksi biji basah dan biji kering per plot dan pada parameter produksi biji basah dan biji kering per hektar, sedangkan pengaruh tidak 
nyata terdapat pada parameter produksi biji basah dan biji kering per sampel.Perlakuan insektisida nabati (ekstrak daun pepaya) yang terbaik yaitu $I_{3}$ dengan dosis 1,5 kg/10 liter air.Perlakuan insektisida kimia (Alika) yang terbaik yaitu $\mathrm{I}_{8}$ dengan dosis 0,5 ml/l air.

\section{SARAN}

Berdasaran hasil penelitian yang dilakukan disarankan untukmelakukan penelitian lebih lanjut dalam mengendalikan hama penggerek polong pada tanaman kedelai dengan menggunakan insektisida alami yang lain serta dilakukan di daerah sentral produksi yang memiliki populasi hama penggerek polong yang tinggi agar memperoleh hasil nenelitian yang lebih akurat.

\section{DAFTAR PUSTAKA}

Adisarwanto. T., 2008. Budidaya Kedele Tropika. Penebar Swadaya. Jakarta

Akmal, 2009. Teknologi Budidaya Kedele. Balai Pengkajian Teknologi Pertanian Sumatera Utara, Medan

Anonymus, 2010. Brosur Pestisida Alika. PT. Syngenta. Indonesia.

Cahyono B. 2007. Teknik Budi Daya Dan Analisis Usaha Tani.CV Aneka Ilmu. Jl.SemarangDemak.

Dirjen Tanaman Pangan, 2000. Pedoman Pengenalan dan Pengendalian Hama Tanaman Kedelai. Sumut.

Endyah Murniati, 2006. Si Mungil Kedele Seribu Manfaat. Penebar SIC. Surabaya

Kalie, Baga Moehd. , 2006. Bertanam Pepaya. Jakarta : Penebar Swadaya.

Kardinan, A. 2009, Pestisida Nabati : Ramuan dan Aplikasi. Jakarta : Penebar Swadaya.

Kartasapeotra, 2003, Hama Tanaman Pangan dan Perkebunan. Bumi Aksqara Jakarta.

Komisi Pestisida Departemen Pertanian RI, 2000. Pestisida untuk Pertanian dan Kehutanan, Jakarta : Koperasi Daya Guna.

Muljana, Wahju. 2002. Bercocok Tanam Pepaya. Semarang : Aneka Ilmu.

Novizan. 2002. Membuat dan Memanfaatkan Pestisida Ramah Lingkungan. Jakarta : Agro Media Pustaka. 
Prayogo Y dan Suharsoho, 2005. Optimalisasi Pengendalian Hama Penghisap Polong Kedelai (Riphortus linearisi) dengan Cendawan Entomopatogen Verticillium lecanii. Jurnal Balai Penelitian Tanaman Kacang-kacangan dan Umbi-umbian, Malang.

Reza, V. T. dan Gayatri,2003. “Pestisida Makin Selektif di Masa Depan.Bisnis Indonesia.

Setiawati, W. Dan Muharram, A. 2003. Pengembangan dan Pengendalian Hama Penting Pada Tanaman. Balai Penelitian Tanaman Sayuran, Lembang.

Sugeng HR, 2010. Bercocok Tanam Palawija. Aneka Ilmu. Demak

Suharmadji, D., 2001, Pepaya, Insektisida Alami. Trubus. Thn. XI.

Suharto, 2007. Pengenalan dan Pengendalian Hama Tanaman Pangan. Andi, Jakarta.

Suprapto, H. 2008. Bertanam kedele. Penebar Swadaya. Jakarta

Wudianto, Rini, 2007, Pengendalian Hama Tanaman Kedelai, Jakarta : Erlangga.. 